\title{
Effect of Inorganic Fertilizer and Sowing Methods on Tef (Eragrostistef (Zucc.) Trotter) Production in Ethiopia: Review
}

\author{
Ketema Berecha* Abdisa Mokonin \\ Ambo University, College of Agriculture, Department of Plant Sciences, Ethiopia \\ Ethiopian Institute of Agricultural Research, Holeta Agricultural Research Center
}

\begin{abstract}
Summary
Tef [Eragrostistef (Zucc.) Trotter] is one of the major small cereal crops in Ethiopia in terms of production and consumption. But in Ethiopia, it is yield low as compared with other major cereal crops growing due to many production constraints such as low soil fertility, lack of appropriate management practices, minimum use of improved varieties, and lack of location specific fertilizer recommendation. Synthetic fertilizer and sowing method have great role on yield and yield components of Tef. So, objective of this study is to review the effects of inorganic fertilizer and sowing methods on yield and yield components of Tef in Ethiopia. Most research work so far focused on NP requirements of crops, but limited information is available on various sources of fertilizers like $\mathrm{S}, \mathrm{Zn}, \mathrm{B}$ and other. Tef responds differently to fertilizer rates and types depending on soil type and cultivars. Application of other sources of nutrients beyond urea and DAP, especially those containing S, Zn, B and other micro-nutrients and different method of sowing could increase Tef crop production and productivity in different area and different agro ecology. Therefore, to increase the production and productivity of tef in country use of Synthetic fertilizer and row sowing are important.
\end{abstract}

Keywords: Inorganic Fertilizer, Sowing Methods, Yield

DOI: $10.7176 / \mathrm{JNSR} / 12-4-03$

Publication date: February $28^{\text {th }} 2021$

\section{INTRODUCTION}

Tef (Eragrostistef (Zucc.) Trotter) is a small grain cereal indigenous and has been recognized that Ethiopia is the center of origin and diversity of tef (Vavilov, 1951). It is most probably domesticated thousands of years ago before the birth of Christ in Ethiopia (Seyfu ,1997). Tef has got both cultural and economic value for Ethiopian farmers with more than six million households' life depending on the production of tef. It is a daily staple food for about 57.2 million people of Ethiopia, and this accounts for more than $64 \%$ of the total population of the country (ATA, 2013a). In Ethiopia, tef is primarily grown for its grain that is used for preparing injera, which is a staple and very popular food in the national diet of most Ethiopians. It can also be used in many other food products, such as kitta, anebaberro, gruel, and local alcoholic beverages, such as tella and katikala (Seyfu ,1997). According to Patricia and Lisette (2008) tef is rich in energy (353-367 K cal/100 g), fat (2.6\%), protein (8-15\%) and gluten free and also is reported rich in iron, calcium, potassium and phosphorus.

Tef is adapted to a wide range of environments and presently it is cultivated under diverse agro-climatic conditions (Mitiku, 2008). Tef has a short growing season with rainfall needs of 450-550 mm, and temperature range of $10-27^{\circ} \mathrm{C}$ (Nadian et al., 2010). Tef is day length sensitive and flowers best during 12 hours of daylight. $T e f$ is well adapted to a wide range of soil types. It has the ability to perform well in black soils and, in some cases, in low soil acidities. In addition, have capacity to withstand waterlogged, rainy conditions, often better than other cereal grains except rice (ATA, 2013b). The major tef producing regions in Ethiopia are Shewa, Gojam, Gonder, Wellega, Wollo, Keffa and Ilubabor (Shorrocks, 1997). Currently, in Ethiopia out of the total grain crop area, $81.39 \%(10,358,890.13$ hectares) was under cereals. Of them tef is first rank in area of production $(3.07 \mathrm{M} \mathrm{ha})$ and second ranks in terms of production $(5.4 \mathrm{M} \mathrm{t})$ which followed by Maize. But it is productivity (17.56) is very low as compared with productivity of other grain cereal crops yield potential (CSA, 2019).

The low tef crop productivity could be due to a complex interaction among the environments, lack of appropriate management practices, biotic and abiotic stresses. Of these, soil fertility problem is one of the major causes of temporal and spatial yield variability (Brhan, 2012). The soil fertility mapping project in Ethiopia reported the deficiency of $\mathrm{S}, \mathrm{Zn}, \mathrm{B}$ and $\mathrm{Cu}$ in addition to $\mathrm{N}$ and $\mathrm{P}$ in major Ethiopian soils (Ethio-SIS, 2014). The broadcasting method that farmer use now days which contributes to the insufficient and poor productivity of tef. Now day's row drilling method and transplanting a young tef seedling that increases the tiller number, producing strong tiller culms and it increases yield and quality of seeds (Tekalign et al., 2001). Therefore, application of other sources of nutrients beyond urea and DAP, especially those containing $\mathrm{S}, \mathrm{Zn}, \mathrm{B}$ and other micro-nutrients, (CSA, 2017) and newly introduced row and transplanting method of sowing could increase tef crop productivity (Tareke et al., 2011). So, objectives of this study to review the effects of Inorganic fertilizer and sowing methods on yield and yield components of tef. 


\section{EFFECT OF INORGANIC FERTILIZER AND SOWING METHODS ON TEF PRODUCTIO IN ETHIOPIA}

\subsection{Importance of inorganic nutrient in tef crop production}

Plants require nitrogen in the largest amounts among the soil nutrients for growth and development. Among the macro nutrients, $\mathrm{N}$ is ranked first in limiting sustainable crop production. An adequate supply of $\mathrm{N}$ is used properly in conjunction with other soil fertility inputs, can speed up the maturity of crops such as small grains (Tisdale et al., 2002). Mulugeta (2003) found that application of high rates of $\mathrm{N}$ fertilizer increased the number of fertile panicles of tef. Increased $\mathrm{N}$ levels dramatically increased grain yield in tef due to increase in yield components. Different research findings show that an increase in fertilizer rate increased the total dry matter content in tef (Tareke et al., 2011). Successive increase in $\mathrm{N}$ rates increased dry matter accumulation and straw yield of tef (Mulugeta, 2003).

As applied $\mathrm{N}$ rates increased, the grain uptake also increased which was also reflected in the plant height, yield and yield components like panicle length, panicle weight, grain yield, straw yield and biomass yield (Legesse, 2004). Selamyihun et al. (1999) also reported that nitrogen content (\%) in tef seed increased with each increment in $\mathrm{N}$ fertilizer, while $\mathrm{N}$ content (\%) in tef straw increased only up to the intermediate level of $\mathrm{N}$ fertilizer applied. Temesgen (2001) stated that Excess N supply causes higher photosynthetic activity and more vegetative growth accompanied by weak stem, long internode, droopy leaf and increases susceptibility to lodging. Phosphorus is the second most essential element for crop production in order to achieve maximum yields. A good supply of $\mathrm{P}$ has been associated with increased root growth and a stiff stalk to resist lodging (Miller and Donahue, 1995). In cereal crops, good P nutrition strengthens structural tissues such as straw or stalks, thus, helping to prevent lodging (Brady and Weil, 2002). According to Legesse (2004), the total P uptake was significantly increased as applied $\mathrm{P}$ rate increased but this increase was not at all reflected in an increase in growth, yield and yield components. Alemayehu et al. (2006) indicated that the grain yield of tef is increased with application of $\mathrm{P}$ fertilizer in different soil type.

Sulfur is required in similar amount as that of phosphorus and constitutes 0.2 to $0.5 \%$ dry matter accumulation in crop tissue (Ali et al., 2008). Sulfur deficiencies are often misdiagnosed as nitrogen problems, leaving growers to wonder why their nitrogen applications are ineffective. In many crops, an acute sulfur deficiency causes the entire plant to turn yellow. In crops like maize and small grains, however, yellow stripes that run parallel to the leaf blade are common. Sulfur deficiency is most frequently observed on very sandy soils with low organic matter content during seasons of excessive rainfall (Brady and Weil, 2002). The most important role in such an increase of grain yield was performed by the number of grains per ear as one of the yield components (Nadian et al., 2010). According to Habtegebre'el and Singh (2006) found that combined N and $\mathrm{S}$ fertilization increased the dry matter and grain yields of tef on average by 1.7 and $0.3 \mathrm{~kg} \mathrm{ha}^{-1}$.

Boron is an essential element for better utilization of macro-nutrients by plants and there by greater translocation of photo-assimilates from source to sink during growth period (Ali et al., 2013). It is involved in the transport of sugars across cell membranes and in synthesis of cell wall material (Singh et al., 2015). Its deficiency results in low grain set, poor seed quality and interferes rapidly with cell division, cell membrane permeability and often results in phenolic compounds accumulating in plant tissue (Shorrocks, 1997). Zinc is an essential element for plants, animals and human beings. Increased risk of $\mathrm{Zn}$ deficiency in human beings is attributed to low levels of $\mathrm{Zn}$ intake. People in developing countries consuming mostly cereals have low $\mathrm{Zn}$ in their diet (Cakmak et al., 2001). Tareke et al. (2011) explained that tef responds highly when treated with Zinc. Populations that depend on tef grain and straw, respectively, as major source of $\mathrm{Zn}$. Tef $\mathrm{Zn}$ concentration has been reported to be low (Wakjira, 2018).

\subsection{Effect of Inorganic Fertilizer on Tef production}

Different studies in various environments at different years reported that tef responds to inorganic fertilizer. Mitiku (2008) stated that application of $69 \mathrm{~kg} \mathrm{~N} \mathrm{ha}^{-1}$ was the best to obtain high total biomass yield, straw yield and grain yield. Similarly, Legesse (2004) found that, high yield components were recorded in response to application of $69 \mathrm{~kg} \mathrm{~N} \mathrm{ha}^{-1}$. As applied $\mathrm{N}$ rates increased, the grain uptake also increased which was also reflected in the plant height, yield and yield components like panicle length, panicle weight, grain yield, straw yield and biomass yield. The studies carried out at Oromia and Tigray region of Ethiopia showed that application of $69 \mathrm{~kg} \mathrm{~N} \mathrm{ha}^{-1}$ increase grain yield of tef but not significance difference from application of $46 \mathrm{~kg} \mathrm{~N} \mathrm{ha}^{-1}$ at two regions as showed in table 1. Temesgen (2001) also reported that the application of different levels of $\mathrm{N}$ fertilizer affected grain, straw and biomass yield significantly on farmer's field where increasing $\mathrm{N}$ fertilizer rate consistently increased Tef grain yield from $1620 \mathrm{~kg} \mathrm{ha}^{-1}$ in the control treatment to $1950 \mathrm{~kg} \mathrm{ha}^{-1}$ in the $69 \mathrm{~kg} \mathrm{~N}$ $\mathrm{ha}^{-1}$ rate was applied. 
Table1. Effects of Nitrogen on grain yield of Tef at Vertisols of Oromia and Tigray

\begin{tabular}{cccc}
\hline \multirow{2}{*}{ No } & $\begin{array}{c}\text { Nitrogen } \\
\left(\mathrm{kg} \mathrm{ha}^{-1}\right)\end{array}$ & $\begin{array}{c}\text { Oromia } \\
(\text { Vertisols })\end{array}$ & $\begin{array}{c}\text { Train yield }\left(\mathrm{kg} \mathrm{hay}^{-1}\right) \\
\text { (Vertisols) }\end{array}$ \\
\cline { 3 - 4 } & 0 & $2551^{\mathrm{c}}$ & $2111.33^{\mathrm{c}}$ \\
2 & 23 & $2809^{\mathrm{bc}}$ & $2830.67^{\mathrm{b}}$ \\
3 & 46 & $3055^{\mathrm{a}}$ & $3379.67^{\mathrm{a}}$ \\
4 & 69 & $3249^{\mathrm{a}}$ & $3443.67^{\mathrm{a}}$ \\
\hline & LSD & 302.92 & 78.05 \\
\hline
\end{tabular}

Source: [Giday et al., 2014; Seifu , 2018.]

Mehreteab (2008) reported that panicle length, plant height, number of nodes, number of effective tillers, lodging index, biomass yield, grain yield and harvest index increased with an increased level of phosphate fertilizer and the optimum grain yield was obtained by applying phosphate fertilizer rate of $46 \mathrm{~kg} \mathrm{P}_{2} \mathrm{O}_{5} \mathrm{ha}^{-1}$. Bereket et al. (2014) reported that increasing P rate from 46 to $69 \mathrm{~kg} \mathrm{P2O5} \mathrm{ha-1} \mathrm{increased} \mathrm{grain} \mathrm{yield} \mathrm{of} \mathrm{bread}$ wheat by about $6.8 \%$. Alemayehu et al. (2006) indicated that the highest grain yield was obtained with the highest P fertilizer rate $\left(80 \mathrm{~kg} \mathrm{P}^{2} \mathrm{O} 5 \mathrm{ha}^{-1}\right)$ in most localities of Vertisols and the highest grain yield in most localities of Nitosols were obtained at $60 \mathrm{~kg} \mathrm{P}^{2} \mathrm{O} 5 \mathrm{ha}^{-1}$ with interaction of 100 and $60 \mathrm{~kg} \mathrm{~N}^{-1} \mathrm{a}^{-1}$, respectively.

According to Habtegebrial and Singh (2006) found that combined N and S fertilization increased the dry matter and grain yields of tef on average by 1.7 and $0.3 \mathrm{~kg} \mathrm{ha}^{-1}$, compared with the control and $\mathrm{S}$ fertilization increased the nitrogen use efficiency of the tef crop by 36\%. Mulugeta and Shiferaw (2017) Suggested in Ethiopia application of suboptimal levels of mineral fertilizers aggravates the decline in soil fertility. Application of $150 \mathrm{~kg}$ NPS $(63: 25: 10.5)+34.5 \mathrm{~kg} \mathrm{~N}^{-1}$ gave highest grain yield. Seifu (2018) reported that the highest grain yield $\left(3228 \mathrm{~kg} \mathrm{ha}^{-1}\right)$ of tef was obtained at the highest rate of blended (150 kg NPSB ha $\left.{ }^{-1}\right)$ fertilizer application, while the lowest grain yield of $2503 \mathrm{~kg} \mathrm{ha}^{-1}$ was recorded from non-treated (control) plot.

According to Fayera et al. (2014) the maximum tef grain yield was obtained with the highest total nitrogen, phosphorus, potassium and zinc uptake. Application of blended fertilizer gave maximum tef yield over NP fertilizer. Application of $100 \mathrm{~kg} \mathrm{NPSZnB} \mathrm{ha}^{-1}$ produced the maximum grain yield $\left(1386.5 \mathrm{~kg} \mathrm{ha}^{-1}\right)$ of tef, while the lowest grain yield $\left(1085.8 \mathrm{~kg} \mathrm{ha}^{-1}\right.$ ) was obtained under the control treatment (Teshome, 2018). Lemlem (2002) also reported that application of blended fertilizer, DAP and urea significantly increased the N, P, K, Zn, $\mathrm{Mg}$ and $\mathrm{S}$ concentrations tef grains and increased grain yield in Vertisols. Application of blended fertilizer increase tef yield from 12.4 to $39.6 \%$ over the control plots.

\subsection{Response of Crops to Sowing Method}

\subsubsection{Broadcasting}

Broadcasting as one of the seed sowing methods, and in combination with reduced cultivation offers the advantage of being up to four times faster than conventional ploughing and drilling and is of particular value for sowing large hectare of winter cereals (Ball, 1996). Under the current farmers' production system, Tef seeds are sown on the surface of the soil and left uncovered or sometimes covered very lightly by pulling woody tree branches over the field using oxen (Seyfu ,1997). The broadcasting system with poor quality of seed, poor soil fertility, and seed rate which is $25-50 \mathrm{~kg} / \mathrm{ha}$ which make the mature plant to lodge i.e. fall over. All these things affected the production of Tef. One of the risks associated with higher plant populations is the increased potential for lodging which can impact yield and quality. This may be particularly true under high yield environments like the Red River Valley (Tareke, 2008).

\subsubsection{Row planting}

In order to avoid uneven stands, improve tillering, improve yield attributing parameters, to reduce lodging and decrease competition among plants, row sowing is preferred although it is tedious, time taking and needs educated person (Hunt, 1999). Row planting of teff seed is considered to be superior compared to the traditional broadcasting method because a reduced seed rate decreases competition between the seedlings for water and nutrients. Moreover, the even distribution of the teff seedlings makes weeding easier and less costly. In research trials, row planting has been shown to increase teff yields up to three times average yields and lowers seed costs, making it seemingly a good value proposition for teff farmers (Berhe et al., 2011). According to Tareke (2008) best results came from spacing and row sowing increases tiller number, producing strong and fertile tiller culms, and increase the number of seeds/panicles of Tef.

\subsubsection{Transplanting Methods}

According to Tareke (2008) planting seedlings on a flat bed and transplanting those into the field showed a promising result. For example, it reduces the seed rate from the broadcasting method and in the new method 2$2.5 \mathrm{~kg} / \mathrm{ha}$ would be enough for a hectare. Moreover, it increases tiller number, producing strong tiller culms and it increases number and quality of seeds. As the researcher explained, the yield of the broadcasting plot was 500- 
$1200 \mathrm{~kg} / \mathrm{ha}$, On the other hand, the transplanted ones gave 3,400-5,100 kg/ha with a fourfold increase in grain yield. In addition, the straw yield also increased from the transplanted grain.

Table 2. Summary benefits and drawbacks planting method of Tef

\begin{tabular}{llll}
\hline No. & Planting methods & Benefits & Draw backs \\
\hline 1 & Broad casting & - Easy sowing method & - Difficult to control plant population \\
& & - Low labour cost & - High cost for seed \\
& & - High susceptibility to lodging \\
& & - Low yield capacity \\
\hline 2 & Row Sowing & - High grain yield & - High cost for labour than broad casting \\
& & - Reduce cost for seed & \\
& - Reduce problem of lodging & \\
\hline 3 & Transplanting & - Easy management practice & - Very high labour cost \\
& & - High grain yield & - Complex and difficult to apply seed \\
& & - Reast cost for seed & \\
& & - Easy management practice & \\
& - Reduce moisture stress & \\
& - Responsive to fertilizer application & \\
& & - Increased plant height, panicle length and tiller capacity
\end{tabular}

Source: [Abraham et al., 2016; Chanyalew and Kebede, 2013]

\subsection{Effects of sowing method on yield and yield components of Tef}

It has been argued recently that low Tef productivity is partly caused by the way farmers sow Tef seed. Traditionally, farmers broadcast the seed using a rate of $25-50 \mathrm{~kg}$ per hectare. According to ATA (2013a) report most of the farmers who employed new Tef technologies experienced yield increases across all regions. Row planting and transplanting technologies produced especially high yields, on average increasing yields by $70 \%$ from the national average of 12.6 quintals/ha to 20.9 quintals/ha. In Amhara and Oromia transplanting produced the highest yields followed by row planting and broadcasting. In SNNP and Tigray row planting produced the highest average yields of 22 and 21 quintals/ha respectively. Transplanting in SNNP and Tigray produced the second highest average yield, with broadcasting producing the lowest in comparison to the other two technologies.

Table 3. Effect of sowing methods on yield of Tef at different region of Ethiopia

\begin{tabular}{ccccc}
\hline \multirow{2}{*}{ No } & Treatment & \multicolumn{3}{c}{ Grain yield(kg/ha) } \\
\cline { 3 - 5 } & Broad casting & $\begin{array}{c}\text { Southern Ethiopia } \\
\text { Vertisols }\end{array}$ & $\begin{array}{c}\text { DZARC (Oromia) } \\
\text { Vertisols }\end{array}$ & $\begin{array}{c}\text { Shebedino (SNNP) } \\
\text { Clay Loam }\end{array}$ \\
\hline 1 & $1497^{\mathrm{b}}$ & $2011^{\mathrm{b}}$ & $995.45^{\mathrm{b}}$ \\
2 & Row Sowing & $1992^{\mathrm{a}}$ & $2167^{\mathrm{a}}$ & $1324.0^{\mathrm{a}}$ \\
\hline & 0.63 & 112.6 & 149.9 \\
\hline & LSD & 10.63 & 8.5 & 19.9 \\
\hline
\end{tabular}

Source: [Abraham et al., 2016]

In Tigray for instance broadcasting yields were 17 quintals/ha, a 30\% increase over the national average. As planting method was only one component of the Teff technology package, this increase in yield from broadcasting compared to the national average can be attributed to the other components of the package (ATA,2013a). Broad casting practice reduces yields because of the uneven distribution of the seeds, higher competition between plants for inputs (water, light and nutrients), and difficult weeding once the plants have matured (Fufa et al., 2011)

As a solution, it has been proposed to reduce seed rates and to plant seed in rows or to transplant seedlings (as is often done for rice, for example). Reducing the seed rate to between 2.5 and $3 \mathrm{~kg}$ per hectare allows for reduced competition between seedlings and optimal tillering of the Tef plants. By row planting or transplanting the seeds, land management and especially weeding can also be done more readily and the incidence of lodging is reduced ( Berhe et al., 2011). Tareke et al. (2011) reported that transplanting sowing method of tef increased grain yield by increasing productive tillers and reducing lodging. The significant increase in grain yield in response to using transplanting might be attributed due to less competition for growth resource like water, sunlight and nutrients, better air circulation which reduces the occurrence of insect pest and disease infestation and also uniform plant stands given opportunity to suppress weed growth (Wakjira, 2018).

2.5. Effects of Inorganic fertilizer and sowing Method on yield and yield components of Tef Many Authors suggested Synthetic fertilizer and sowing Method on Tef affects yield and yield components of 
Tef in different way and different area. Shiferaw (2012) reported that application of Blended fertilizer in a row sowing gave (3700-4000 kg/ha) grain yield than the rest of the treatments at different site (Table 4).

Table 4. Effects of sowing methods and fertilizer types on grain yield of tef

\begin{tabular}{|c|c|c|c|c|c|c|c|c|c|}
\hline \multirow[b]{4}{*}{ No } & \multirow[b]{4}{*}{ Fertilizer Type } & \multicolumn{8}{|c|}{ Grain yield $\left(\mathrm{kg} \mathrm{ha}^{-1}\right)$} \\
\hline & & \multicolumn{4}{|c|}{ Oromia (Shewa) } & \multicolumn{4}{|c|}{ Oromia (Wollega) } \\
\hline & & \multicolumn{2}{|c|}{ Denkaka } & \multicolumn{2}{|l|}{ Ude } & \multicolumn{2}{|c|}{ Gabate } & \multicolumn{2}{|l|}{ Kobo } \\
\hline & & Vertisol & & Vertisol & & Nitosol & & Nitosol & \\
\hline & & $\mathrm{B} /$ cast & Row & $\mathrm{B} /$ cast & Row & $\mathrm{B} /$ cast & Row & $\mathrm{B} /$ cast & Row \\
\hline 1 & No fertilizer & 1583 & 1419 & 1150 & 833 & 455.67 & 447.33 & 418.3 & 416.33 \\
\hline 2 & DAP + Urea & 3317 & 3681 & 3347 & 3847 & 3155 & 3189.33 & 3122.3 & 3164 \\
\hline \multirow[t]{2}{*}{3} & Blended & 3208 & 3986 & 3305 & 3722 & 3110.33 & 3250.67 & 3025.67 & 3222.67 \\
\hline & Mean & 2703 & 3029 & 2601 & 2801 & 2295.78 & 2295.78 & 2188.78 & 2267.67 \\
\hline
\end{tabular}

Source: [Refissa 2012; Shiferaw, 2012]

Significantly lower (830-1500 kg/ha) grain yield was recorded under unfertilized conditions in both broadcast and row sowing at both sites. Application of Blended fertilizer increased grain yield by $102-109 \%$ at the two sites as compared to the control treatment (broadcast sowing and non-fertilized). Similarly, Refissa (2012) reported that row sowing method and Blended fertilizer increase tef grain yield than the rest of the treatments at different site (Table 4). Tareke et al. (2012) who reported that transplanting increased grain yield by increasing productive tillers and reducing lodging. Similar results also reported blended fertilizer increased grain yield of tef. Transplanting combined with blended fertilizer increased grain yield by $50 \%$ than using DAP or Urea fertilizer, and this increment in grain yield is mainly due to the number of tillers and number of panicles.

\section{Conclusions}

Tef is the most widely grown cereals in Ethiopia. It is a staple diet of the majority of the population, and it is most widely planted by Ethiopian farmers and also gaining popularity as a health food in the western world. Ethiopia is the center of origin and diversity of Tef. Ethiopian farmers have been growing Tef for both the grain and straw yeilds. In addition to this, tef is excellently adapted to the changing environments in the country, and thereby suffer low production risks. The principal limitation of Tef cultivation in Ethiopia is the low productivity due to un balanced and sup optimal use of in organic fertilizer and use of broad casting sowing method. Both sowing method and fertilizer types affected yield of tef in Ethiopia. Row sowing reduces seed rate by five times as compared to broadcast sowing and transplanting method reduces seed rate by ten times row sowing method. Application of different nutrient great role in growth, development as well as in yield and yield components of Tef and also nutrient up takes from the soil. Application of different levels of micro primary and secondary nutrients affected growth, yield and yield components of tef. But Ethiopian agriculture has emphasized only on N, P and K-fertilizer inputs. The application of micro element such as Sulfur (S), Zinc (Zn), Boron (B) and others not well known in Ethiopia. The proper application of these micro nutrients with good sowing method has increase yield and yield components of tef. Types of fertilizer whether it is complete or incomplete, macro or micro how it applied, practice sowing method and spacing all this affect the yield and yield components of tef. The best grain yield of Tef can be improved through use of blended in organic fertilizer application and transplant or row sowing method. Therefore, the growers, farmers, researchers and all stakeholders' give attentions in use of blended fertilizers that contain Micro and micro nutrients and sowing methods of tef to increase the yield.

\section{Reference}

Abraham Reda, Nigussie Dechassa and Kebebew Assefa, 2016. Evaluation of Seed Rates and Sowing Methods on Growth, Yield and Yield Attributes of Tef [Eragrostistef (Zucc.) Trotter] in Ada District, East Shewa, Ethiopia. American-Eurasian Journal of Agriculture and Environmental Science, 18 (1): 34-49

Alemayehu Assefa, MinaleLiban, TilahunTaddese and Abrham Marye, 2006. Determination of optimum rates of Nitrogen and Phosphorus fertilization for Tef [Eragrostistef (Zucc.) Trotter] production in different agro ecological areas of northwestern Ethiopia, Annual Regional Conference in Bahirdar, 1:36-49.

Ali, M. A., Tariq, N. H., Ahmed, N., Abid, M. and Rahim, A., 2013. Response of Wheat (Triticum aestivum L.) to Soil Applied Boron and Zinc Fertilizers under Irrigated Conditions. Pakistan Journal of Agriculture Agricultural Engineering and Veterinary Sciences, 29 (2): 114-125.

Ali, R., Khan, M.J. and Khattab, R.A., 2008. Response of rice to different sources of sulfur at various levels and its residual effect on wheat in rice-wheat cropping system. Journal of Soil Environment, 27(1): 131-137.

ATA (Agricultural Transformation Agency), 2013a. Results of 2012 New Tef Technologies Demonstration Trials Draft Report VF. Addis Ababa, Ethiopia.

ATA (Agricultural Transformation Agency), 2013b.Working Strategy for Strengthening Ethiopian's Tef Value Chain Vision, Systemic Challenges, and Prioritized Interventions. 
Ball, B. C., 1996 Cereal production with broadcast seed and reduced tillage review of recent experimental and farming experience. Journal of Agricultural Engineering Research, 35(2), 71-95.

Bereket Haileselassie, Dawit Habte, Mehretab Haileselassie, Gebremedhin Gebremeskel, 2014. Effects of Mineral Nitrogen and Phosphorus Fertilizer on Yield and Nutrient Utilization of Bread Wheat (Tritcum aestivum L.) on the Sandy Soils of Hawzen District, Northern Ethiopia. Agriculture, Forestry and Fisheries, 3(3): 189-198.

Berhe, T., Z. Gebretsadik, S. Edwards, and H. Araya, 2011. Boosting Tef Productivity Using Improved Agronomic Practices and Appropriate Fertilizer." the Second International Workshop, November 7-9, 2011, Debre Zeit, Ethiopia.

Brady, N.C. and Weil, R.R., 2002. The Nature and Properties of Soils, $13^{\text {th }}$ edition Pearson Education Ltd, USA.

Brhan Abayu, 2012. Agronomic and Economic Effects of Blended Fertilizers under Planting Method on Yield and Yield Components of Tef. M.Sc.Thesis, Mekelle University Mekelle, Ethiopia.

Cakmak, O., L. Ozturk, S. Karanlik, H. Ozkan, Z. Kaya, and I. Cakmak., 2001. Tolerance of 65 durum wheat genotypes to zinc deficiency in a calcareous soil. Journal of Plant Nutrition, 24: 1831-1847.

Chanyalew Sebsebe and Kebede Assefa, 2013. The agronomy of tef. Paper presented at the "Improved evidence towards better policies for the teff value chain" conference, 10 October 2013, Addis Ababa, Ethiopia. DOI: http://dx.doi.org/10.2147/idr.s134369

CSA (Central Statistics Agency), 2017. The Federal Democratic Republic of Ethiopia, Agricultural Sample Survey 2016/2017 (2009 E.C.). Report on Area and production of major Crops Addis Ababa, Ethiopia. Statistical Bulletin 584.

CSA (Central Statistics Agency), 2019. Agricultural sample survey of 2018/2019 Report on area and production of major crops for private peasant holdings, meher season. Addis Ababa, Ethiopia Statistical Bulletin 589.

Ethio-SIS (Ethiopian Soil Information System), 2014. Soil Analysis Report. Agricultural Transformation Agency Ababa, Ethiopia pp 76.

Fayera Asefa, Adugna Debela \&Muktar Mohammed.2014 Evaluation of Tef [Eragrostistef (Zuccagni) Trotter] Responses to Different Rates of NPK Along with Zn and B in Didessa District, Southwestern Ethiopia. World Applied Sciences Journal, 32 (11): 2245-2249.

Fufa, B., B. Behute, R. Simons, and T. Berhe, 2011. Tef Diagnostic Report: Strengthening the Tef Value Chain in Ethiopia". Addis Ababa, Ethiopia.

Giday O, Gibrekidan H, Berhe T. 2014 Response of Tef [Eragrostistef (Zuccagni) Trotter] to different rates of slow release and conventional urea fertilizers in vertisols of southern Tigray, Ethiopia. Advanced Plants Agriculture Research, 1(5):190-197.

Habtegebrial Kiros and Singh, B.R., 2006. Effects of timing of nitrogen and sulphur fertilizers on yield, nitrogen, and sulphur contents of Tef [Eragrostistef (Zuccagni) Trotter] Nutrient Cycling in Agro-ecosystems, 75: 213-222

Hunt, D., 1999. Farm power and machinery management, 8th ed., Iowa State University

Legesse Admassu. 2004. Response of Tef [Eragrostistef (Zucc.) Trotter] to Phosphorus and Nitrogen Application in North Eastern Ethiopia.M.Sc. Thesis, Alemaya University, Dire Dawa, Ethiopia.71 pp.

Lemlem Hiwot, 2012. Evaluating the effect of low seeding rate, planting method and blended fertilizer application on Tef [Eragrostistef (Zuccagni) Trotter] (Kuncho variety) yield, yield component and nutrient uptake by grain grown on Regosols and Vertisols.

Mehreteab Haileselassie, 2008. Effect of Seed and Phosphate Fertilizer Rates on Yield and Yield Components of Tef [Eragrostistef (Zuccagni) Trotter] on Vertisols of Woreda Laelay Maichew, Central Tigray, Northern Ethiopia. M.Sc. Thesis, Haramaya University, College of Agriculture, Haramaya, Ethiopia.

Miller, R.W. and Donahue, R.L., 1995. Soils in our Environment 7th ed., Prentice Hall Englewood Cliffs, New Jersey, USA.

Mitiku Melaku. 2008. Effect of Seeding and Nitrogen Rates on Yield and Yield Components of Tef [Eragrostis tef (Zucc.) Trotter] at Adet North Western Ethiopia. M.Sc. Thesis, Haramaya University, College of Agriculture, Haramaya, Ethiopia.

Mulugeta Gezehagn, 2003. Response of Tef [Eragrostis tef (Zucc.) Trotter] to applied nitrogen and phosphorus in Vertisols of Raya, Tigry. M.Sc. Thesis, Haramaya University, College of Agriculture, Haramaya, Ethiopia.

Mulugeta Habte and Shiferaw Boke, 2017. Influence of balanced nutrients on growth performance and yield of Tef [Eragrostis tef (Zucc.) Trotter] in the midland of Bensa, Southern Ethiopia. Journal of Scientific and Innovative Research ;6(3):101-103

Nadian, H., Najarzadegan, R., Alami Saeid, K., Gharineh, M.H. and Siadat, A., 2010. Effects of boron and sulfur Application on yield and yield components of Brassica napus L. in a Calcareous soil. World Applied Sciences Journal, 11(1): 89-95.

Patricia Arguedas, G. and Lisette van, E. 2008. TEF: Survey on the Nutritional and Health Aspects of Tef 
[EragrostisTef(Zucc.) Trotter] Memorias Red-Alfa LagrotechComunidadEuropea, Cartagena, 319-382.

Refissa Leta 2012 M.Sc. Thesis Effects of Sowing Method and Inorganic Fertilizer Type On Yield and Yield Components Of Tef [EragrostisTef (Zucc.) Trotter] In Guduru District, Western Oromia, Haramaya University Ethiopia, p 67

Seifu Kibebew 2018. Effect of rates of blended NPSB and N fertilizers on yield components and yield of Tef [Eragrostistef (zucc.) Trotter] in HidhebuAbote district, Central EthiopiaM.Sc. Thesis, Alemaya University, Dire Dawa, Ethiopia.61pp.

Selamyihun Kidanu, Tanner, D.G. and TekalignMamo, 1999. Effect of nitrogen fertilizer applied to tef on the yield and $\mathrm{N}$ response of succeeding tef and durum wheat on a highland Vertisol. African Crop Science Journal, 7(1): 35-46.

Seyfu Ketema. 1993. Studies of lodging floral, biology, and breeding techniques in Tef [Eragrostistef (Zucc.) Trotter)]. Ph.D. Thesis presented to the school of graduate studies of University of London.

Seyfu Ketema. 1997. Tef [Eragrostistef (Zucc.) Trotter]. Promoting the Conservation and Use of Underutilized and Neglected crops.12. International Plant Genetics Resources Institute (IPGRI), Biodiversity Institute, Addis Ababa, Ethiopia. 50 pp. Shewa, Ethiopia. Journal of Agricultural Sciences,13(2):162-173

Shiferaw Tolosa, 2012 Effects of inorganic fertilizer types and sowing methods of variable seed rates on yield and yield components of Tef [Eragrostistef (Zucc.) Trotter] in Ada'a Woreda, Central Ethiopia M.Sc.Thesis, Haramaya University, Haramaya, Ethiopia.

Shorrocks, V. M., 1997. The occurrence and correction of boron deficiency. Plant Soil, 193: 121-148.

Singh, L. A., Yadav, R. and Abraham T., 2015. Studies on the effect of Zinc levels, and methods of boron application on growth, yield and protein content of Wheat (Triticum aestivum L.). Bulletin of Environment, Pharmacology and Life Sciences, 4(2): 108-113.

Tareke Berhe, 2008 Increasing Productivity of Tef [Eragrostis tef (Zucc.) Trotter] New Approaches with Dramatic results (Unpublished Report), Addis Ababa, Ethiopia. Ed.) Prentice Hall of India, New Delhi. $684 p$.

Tareke Berhe, Zewdie Gebretsadik, Edwards, S. and Hailu Araya, 2011. Boosting Tef productivity using improved agronomic practices and appropriate fertilizer pp.133140.

Tekalign Mammo, Teklu Erkossa and Balesh Tulema, 2001. Soil Fertility and Plant Nutrition Research on Tef in Ethiopia pp.199-200.

Temesgen Kassa, 2001. Effect of sowing dates and nitrogen fertilization on yield and yield related traits of Tef [Eragrostistef(Zucc) Trotter] on vertisols of Kobo area, North Wollo. M.Sc. Thesis presented to the School of Graduate Studies of Haramaya University.

Teshome Mesfin, 2018. Effects of Nitrogen and Blended Fertilizers on Yield and Yield Components of Tef [(Eragrostistef (Zucc.) Trotter] in Ada'a District, Central Highlands of Ethiopia HawassaUniversity College of Agriculture p 102 Hawassa, Ethiopia.

Tisdale, S.L., Nelson, W.L., Beaton, J.D. and Haulin, J.L., 2002. Soil Fertility and Fertilizers

Vavilov, N.I, 1951. The origin, variation, immunity and breeding of cultivated plants Chronica Botany, 13: 1351.

Wakjira Tesfahun, 2018. Tef Yield response to NPS Fertilizer and Methods of Sowing in East Shewa, Journal of Agricultural Sciences, 13(2):162-173 